\title{
Cystathionine $\beta$-synthase-derived hydrogen sulfide regulates lipopolysaccharide-induced apoptosis of the BRL rat hepatic cell line in vitro
}

\author{
JUN YAN $^{1}$, FEIXIANG TENG ${ }^{2}$, WEIWEI CHEN ${ }^{3}$, YINGLEI JI ${ }^{1}$ and ZHENYONG GU ${ }^{1}$ \\ ${ }^{1}$ Department of Forensic Medicine, Soochow University, Jiangsu 215123; ${ }^{2}$ Department of Physiology, \\ Yancheng Institute of Health Science, Jiangsu 224000; ${ }^{3}$ Department of Anorectal Surgery, \\ Yancheng Third People's Hospital, Jiangsu 224001, P.R. China
}

Received June 20, 2012; Accepted August 13, 2012

DOI: $10.3892 /$ etm.2012.672

\begin{abstract}
Hydrogen sulfide $\left(\mathrm{H}_{2} \mathrm{~S}\right)$, is a member of the novel family of endogenous gaseous transmitters, termed "gasotransmitters exhibiting diverse physiological activities, and is generated in mammalian tissues mainly by cystathionine $\beta$-synthase (CBS), cystathionine $\gamma$-lyase (CSE) and 3-mercaptopyruvate sulfurtransferase (3MST) in conjunction with cysteine (aspartate) aminotranferase (CAT). The distributions of these enzymes are species- and tissue-specific. The liver, as the main organ that generates $\mathrm{H}_{2} \mathrm{~S}$ in vivo, functions in biotransformation and metabolism. However, the liver is vulnerable to damage from internal and external factors, including inflammatory mediators, drugs and poisons. The present study evaluated the endogenous $\mathrm{CBS}-\mathrm{H}_{2} \mathrm{~S}$ synthesis regulating lipopolysaccharide (LPS)-induced apoptosis of hepatic cells. The rat hepatic cell line, BRL, was incubated with LPS for various time periods to establish a cell-damage model. Incubation with LPS resulted in a significant increase in CBS expression and $\mathrm{H}_{2} \mathrm{~S}$ production. It also stimulated apoptosis and decreased the mitochondrial membrane potential. Pretreatment with the CBS inhibitor aminooxyacetic acid (AOAA) or CBS small interfering RNA (siRNA) decreased LPS-enhanced $\mathrm{H}_{2} \mathrm{~S}$ production. Notably, apoptosis increased for a short period and then decreased gradually, while the mitochondrial membrane potential demonstrated the opposite trend. These results showed that endogenous $\mathrm{CBS}-\mathrm{H}_{2} \mathrm{~S}$ synthesis demonstrated early anti-apoptotic activity and subsequent pro-apoptotic activity in LPS-induced apoptosis. These results suggest a new approach for developing novel drugs for this condition.
\end{abstract}

Correspondence to: Professor Zhenyong Gu, Department of Forensic Medicine, Soochow University, 199 Renai Road, Suzhou, Jiangsu 215123, P.R. China

E-mail: guzynt@163.com

Key words: cystathionine $\beta$-synthase, hydrogen sulfide, apoptosis, lipopolysaccharide, BRL

\section{Introduction}

Hydrogen sulfide $\left(\mathrm{H}_{2} \mathrm{~S}\right)$, a novel and important gaseous transmitter, is endogenously generated in mammalian tissues predominantly by two pyridoxal-5'-phosphate-dependent enzymes, cystathionine $\beta$-synthase (CBS) and cystathionine $\gamma$-lyase (CSE), using either L-cysteine or L-homocysteine as a substrate $(1,2)$. Recently, Shibuya et al (3) observed that 3-mercaptopyruvate sulfurtransferase (3MST) in conjunction with cysteine (aspartate) aminotranferase (CAT), as the third $\mathrm{H}_{2} \mathrm{~S}$-producing enzyme, contributes significantly to generating $\mathrm{H}_{2} \mathrm{~S}$ from L-cysteine in the presence of $\alpha$-ketoglutarate. The distribution of these enzymes is species- and tissue-specific, and CBS and CSE are present in the liver (4). $\mathrm{H}_{2} \mathrm{~S}$ has been observed to demonstrate a wide range of physiological functions and is important for several pathological conditions. For example, $\mathrm{H}_{2} \mathrm{~S}$ opens $\mathrm{K}^{+}$-ATP channels in vascular and gastrointestinal smooth muscle cells, neurons and pancreatic $\beta$ cells, regulating vascular tone, intestinal contractility, neurotransmission and insulin secretion (5-8). $\mathrm{H}_{2} \mathrm{~S}$ has also been recognized to be involved in the inflammatory response (9).

Bacterial endotoxins such as lipopolysaccharide (LPS) induce excessive activation and upregulation of vascular $\mathrm{K}^{+}$-ATP channels and hypotension, and substantially reduce vascular sensitivity to vasoconstrictive agents $(10,11) . \mathrm{H}_{2} \mathrm{~S}$ has been proposed as a potential endogenous ligand for $\mathrm{K}^{+}$-ATP channels to induce $\mathrm{K}^{+}$-ATP channel-mediated vasorelaxation (12) in several vascular tissues, suggesting that $\mathrm{H}_{2} \mathrm{~S}$ might be involved in endotoxic shock.

As one of the most important organs in the body, the liver functions in biotransformation and metabolism. Due to its central location in regulating metabolism and response to both physiological and pathological exogenous stimuli, all forms of liver disease are accompanied by a certain degree of inflammation. Therefore, the liver is vulnerable to damage from internal and external factors, including inflammatory mediators, drugs and poisons $(13,14)$. Numerous studies have investigated the overall function and mechanism of this organ and in related research, the role of hydrogen sulfide in hepatic ischemia-reperfusion injury has been reported (15). However, the significance of endogenous $\mathrm{H}_{2} \mathrm{~S}$ (particularly the CBS- $\mathrm{H}_{2} \mathrm{~S}$ 
synthesis) in endotoxemia at the hepatic cell level is rarely discussed.

In the present study, we used the BRL rat hepatic cell line to imitate hepatocytes in vivo. We hypothesized that the endogenous $\mathrm{CBS}-\mathrm{H}_{2} \mathrm{~S}$ synthesis participates in the pathophysiological regulation of apoptosis induced by LPS. To investigate the role of the $\mathrm{CBS}-\mathrm{H}_{2} \mathrm{~S}$ synthesis in the pathogenesis of hepatocyte injury, we added LPS to BRL cells and observed changes in endogenous $\mathrm{CBS}$ expression, $\mathrm{H}_{2} \mathrm{~S}$ concentration in the culture supernatant and regulation of apoptosis following administration of CBS inhibitor or CBS small interfering RNA (siRNA).

\section{Materials and methods}

Materials. LPS (Escherichia coli 0111:B4) and aminooxyacetic acid (AOAA) were obtained from Sigma-Aldrich (St. Louis, MO, USA). Other chemicals and reagents were of analytical grade.

Cell culture. The normal rat hepatic cell line BRL was obtained from the Cell Bank of the Chinese Academy of Sciences, Shanghai, China. BRL cells were cultured at $37^{\circ} \mathrm{C}$ in a humidified incubator with $95 \%$ air and $5 \% \mathrm{CO}_{2}$ in RPMI-1640 medium (Gibco, Invitrogen, Carlsbad, CA, USA) supplemented with $10 \%$ heat-inactivated fetal bovine serum (FBS; Hyclone, Invitrogen), $100 \mathrm{U} / \mathrm{ml}$ of penicillin and $100 \mu \mathrm{g} / \mathrm{ml}$ of streptomycin. Cultured cells were used at 70-80\% confluence.

siRNA. CBS siRNA sequences were designed and synthetized by Invitrogen: siRNA 455-s, 5'-CCAAGUGUGAGUUCUUC AATT-3' and siRNA 455-a, 5'-UUGAAGAACUCACACU UGGTT-3'; siRNA 1283-s, 5'-CCAAGUUCUUGAGUGAC AATT-3' and siRNA 1283-a, 5'-UUGUCACUCAAGAACU UGGTT-3'; siRNA 1739-s, 5'-CCAUUGACCUGCUAAA CUUTT-3' and siRNA 1739-a, 5'-AAGUUUAGCAGGUCAA UGGTT-3'. One OD unit of each siRNA was dissolved in $150 \mu \mathrm{l}$ double-distilled $\mathrm{H}_{2} \mathrm{O}$ and $18 \mu \mathrm{l}$ was mixed with $6 \mu \mathrm{l}$ Lipofectamine $^{\mathrm{TM}} 2000$ Transfection Reagent (Invitrogen) in $550 \mu \mathrm{l}$ serum-free medium for $30 \mathrm{~min}$. This was added to cells in 6-well plates. Western blot analysis was used to detect the efficiency of gene silencing. The most efficient sequence was used to transfect cells for flow cytometry (FCM) dectection.

CBS mRNA assay. Total RNA from BRL cells was extracted using TRIzol reagent (Gibco, Invitrogen). Reverse transcription-polymerase chain reaction (RT-PCR) was performed in a $0.2-\mathrm{ml}$ tube containing $2 \mu \mathrm{l}$ tissue cDNA, $1 \mu \mathrm{l}$ primer mixture of $5 \mu \mathrm{mol} / 1$ of eachCBS-s,5'-GAACCAGACGGAGCAAACAG -3' and CBS-a, 5'-TGTAGAGGACTTTGCAGACT-3' (Invitrogen), $1 \mu 1$ of $2.5 \mathrm{mmol} / 1$ each dNTP, $1.5 \mu \mathrm{l}$ of $1.5 \mathrm{mmol} / \mathrm{l}$ $\mathrm{MgCl}_{2}, 2.5 \mu \mathrm{l}$ 10X PCR buffer and $1.25 \mathrm{U}$ Taq DNA polymerase, in $25 \mu \mathrm{l}$. After incubation at $95^{\circ} \mathrm{C}$ for $5 \mathrm{~min}, \mathrm{PCR}$ was performed at $94^{\circ} \mathrm{C}$ for $30 \mathrm{sec}, 55^{\circ} \mathrm{C}$ for $30 \mathrm{sec}$ and $72^{\circ} \mathrm{C}$ for $40 \mathrm{sec}$ for 30 cycles. The PCR products were separated on a $1.5 \%$ agarose gel and stained with ethidium bromide. The optical density of the band of CBS mRNA (572 bp) was measured using the Gel Documentation System (Bio-Rad, Hercules, CA, USA). PCR products were amplified again at $94^{\circ} \mathrm{C}$ for $30 \mathrm{sec}, 55^{\circ} \mathrm{C}$ for $30 \mathrm{sec}$ and $72^{\circ} \mathrm{C}$ for $30 \mathrm{sec}$ for 20 cycles with rat GAPDH primers: GAPDH-s, 5'-C
CATGACAACTTTGGCATC-3' and GAPDH-a, 5'-ATGTCA GATCCACAACGGA-3' (Invitrogen). The optical density of the GAPDH mRNA band (262 bp) was measured and the ratio of CBS mRNA/GAPDH mRNA was taken to be the relative quantity of CBS mRNA.

Preparation of cell lysates for western blot analysis. After treatment, BRL cells were homogenized in ProteoJET ${ }^{\mathrm{TM}}$ mammaliancell lysis reagent supplemented with ProteoBlock ${ }^{\mathrm{TM}}$ protease inhibitor cocktail (Fermentas, Amsterdam, The Netherlands) and centrifuged at $4^{\circ} \mathrm{C}$ for $15 \mathrm{~min}$ at $16,000 \mathrm{x} \mathrm{g}$. The supernatants were collected and stored at $-80^{\circ} \mathrm{C}$. Protein concentrations were determined by the Bio-Rad protein assay (Bio-Rad).

Western blot analysis. The protein samples (30 $\mu \mathrm{g})$ were separated by SDS-polyacrylamide gel electrophoresis on $10 \%$ Tris-glycine polyacrylamide gels and transferred to nitrocellulose membranes. Nonspecific binding was blocked by incubation for $1 \mathrm{~h}$ in $5 \%$ nonfat dry milk in PBST $(0.05 \%$ Tween-20 in phosphate-buffered saline). The blots were incubated overnight with primary antibody against CBS, cytochrome $c$, or cleaved caspase-3 (Asp175; Santa Cruz Biotechnology, Inc., Santa Cruz, CA, USA) at 1:400 in 2.5\% nonfat dry milk in PBST, followed by washing 4 times with PBST and incubating for $1 \mathrm{~h}$ with goat anti-rabbit horseradish peroxidase-conjugated secondary antibody (Santa Cruz Biotechnology, Inc.) at 1:2,000 in 2.5\% nonfat dry milk in PBST. The membranes were washed and incubated in SuperSignal West Pico chemiluminescent substrate (Pierce Chemical, Rockford, IL, USA) before exposure to X-ray film (CL-XPosure; Pierce Chemical). The gels were calibrated by protein Kaleidoscope standards (Bio-Rad). $\beta$-tubulin (Santa Cruz Biotechnology, Inc.) was used as an internal control to normalize for protein loading. Band intensity was quantified using LabWorks Image Analysis software (UVP Upland, CA, USA).

Measurement of $\mathrm{H}_{2}$ S production. $\mathrm{H}_{2} \mathrm{~S}$ production was measured as described previously $(12,16)$. Briefly, after treatment, cells were collected and homogenized in $50 \mathrm{mM}$ ice-cold potassium phosphate buffer ( $\mathrm{pH}$ 6.8). Flasks containing reaction mixture (100 mM potassium phosphate buffer, $10 \mathrm{mM}$ L-cysteine, $2 \mathrm{mM}$ pyridoxal 5'-phosphate and $10 \% \mathrm{w} / \mathrm{v}$ cell homogenates) and center wells containing $0.5 \mathrm{ml} 1 \%$ zinc acetate and a piece of filter paper were flushed with $\mathrm{N}_{2}$ and incubated at $37^{\circ} \mathrm{C}$ for $90 \mathrm{~min}$. The reaction was terminated by adding $0.5 \mathrm{ml}$ $50 \%$ trichloroacetic acid and flasks were incubated at $37^{\circ} \mathrm{C}$ for $60 \mathrm{~min}$. The contents of the center wells were transferred to test tubes each containing $3.5 \mathrm{ml}$ of water and $0.5 \mathrm{ml}$ of $20 \mathrm{mM} \mathrm{N}, \mathrm{N}$-dimethyl-p-phenylenediamine sulfate in $7.2 \mathrm{M}$ $\mathrm{HCl}$ and $0.5 \mathrm{ml} 30 \mathrm{mM} \mathrm{FeCl}_{3}$ in $1.2 \mathrm{M} \mathrm{HCl}$ were added. The absorbance of the resulting solution at $670 \mathrm{~nm}$ was measured after 20 min with a Multiskan ${ }^{\circledR}$ spectrum microplate spectrophotometer (Thermo Scientific).

Apoptosis. The Annexin V-FITC/PI apoptosis detection kit was purchased from Calbiochem (La Jolla, CA, USA). BRL cells were dispersed by $0.25 \%$ trypsin and $1-5 \times 10^{5}$ cells were collected and washed twice with phosphate buffer (pH 7.4). Cells were suspended in $500 \mu 1$ Annexin V binding 
A
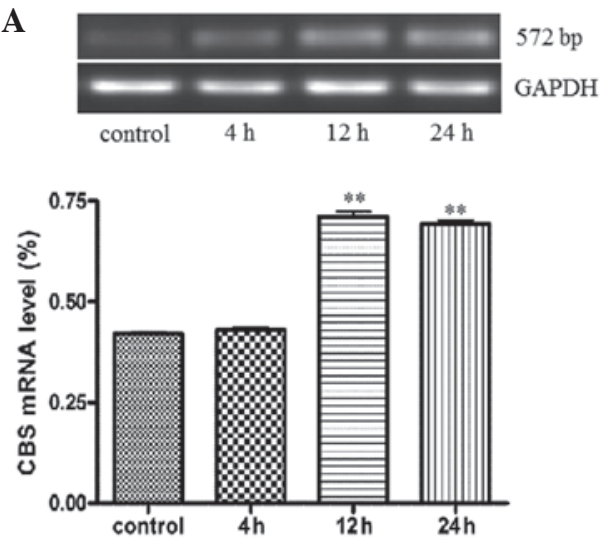

B
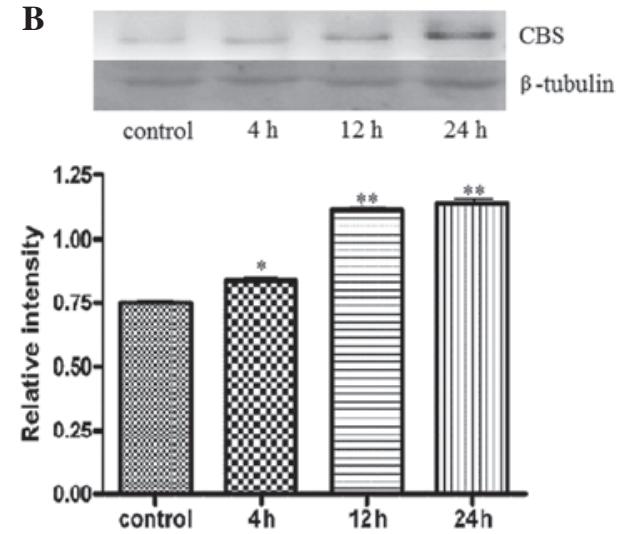

Figure 1. Alteration of endogenous CBS expression in LPS-treated BRL cells. BRL cells were treated with $10 \mu \mathrm{g} / \mathrm{ml} \mathrm{LPS}$ and collected at the indicated times. (A) RT-PCR showing CBS mRNA. (B) Western blot analysis showing CBS protein. Data represent 3 independent experiments. ${ }^{*} \mathrm{P}<0.05,{ }^{* *} \mathrm{P}<0.01$ vs. control. CBS, cystathionine $\beta$-synthase; LPS, lipopolysaccharide; RT-PCR, reverse transcription-polymerase chain reaction.

Table I. Alteration of $\mathrm{H}_{2} \mathrm{~S}$ production in BRL cells $(\mu \mathrm{mol} / \mathrm{l})$.

\begin{tabular}{lcccc}
\hline Groups & Control & $4 \mathrm{~h}$ & $12 \mathrm{~h}$ & $24 \mathrm{~h}$ \\
\hline LPS group & $26.19 \pm 4.93$ & $36.23 \pm 4.23$ & $46.73 \pm 3.44^{\mathrm{a}}$ & $58.23 \pm 2.52^{\mathrm{a}}$ \\
AOAA+LPS group & $26.17 \pm 4.57$ & $24.33 \pm 2.43$ & $19.25 \pm 2.24^{\mathrm{b}}$ & $16.98 \pm 4.02^{\mathrm{c}}$ \\
AOAA group & $26.18 \pm 4.45$ & $24.74 \pm 3.98$ & $18.66 \pm 4.31$ & $13.42 \pm 2.45^{\mathrm{d}}$ \\
CBS siRNA+LPS group & $26.17 \pm 4.77$ & $24.26 \pm 3.23$ & $19.77 \pm 2.27^{\mathrm{b}}$ & $16.22 \pm 3.55^{\mathrm{c}}$ \\
CBS siRNA group & $26.19 \pm 4.66$ & $24.01 \pm 4.11$ & $18.46 \pm 3.37$ & $13.13 \pm 3.01^{\mathrm{d}}$ \\
\hline
\end{tabular}

${ }^{\mathrm{a}} \mathrm{P}<0.01$ vs. control group, ${ }^{\mathrm{b}} \mathrm{P}<0.05$ and ${ }^{\mathrm{c}} \mathrm{P}<0.01$ vs. LPS group, ${ }^{\mathrm{d}} \mathrm{P}<0.05$ vs. control group. LPS, lipopolysaccharide; AOAA, aminooxyacetic acid; AOAA+LPS, pretreated with AOAA prior to the addition of LPS in BRL cells; CBS siRNA, transfection of CBS siRNA in BRL cells; CBS siRNA+LPS, pretreated with CBS siRNA prior to the addition of LPS in BRL cells; CBS, cystathionine $\beta$-synthase; siRNA, small interference RNA.

buffer and mixed with $5 \mu \mathrm{l}$ Annexin $\mathrm{V}$ binding buffer and $5 \mu \mathrm{l}$ propidium iodide, and incubated for $10 \mathrm{~min}$ in the dark at room temperature. Cell apoptosis was detected by FCM (Cytomics FC500; Beckman-Coulter, Miami, FL, USA; Ex=488 nm, $\mathrm{Em}=530 \mathrm{~nm})$.

Mitochondrial membrane potential. BRL cells were cultured on coverslips prepositioned in 6-well plates overnight. After treatment, cells were processed with MitoCapture ${ }^{\mathrm{TM}}$ Apoptosis Detection kit (Calbiochem) and cultured at $37^{\circ} \mathrm{C}$ in a humidified incubator with $95 \%$ air and $5 \% \mathrm{CO}_{2}$ for $20 \mathrm{~min}$. MitoCapture is a cationic dye that exists as a polymer in the mitochondria of normal cells and produces a red fluorescence, or as a green fluorescent monomer in the cytoplasm of apoptotic cells. Results were recorded by fluorescence microscope (Eclipse 90i; Nikon) at x400 magnification.

Lactate dehydrogenase $(\mathrm{LDH})$ release assay. After treatment, BRL-cell medium was collected by centrifugation at $850 \mathrm{x} \mathrm{g}$ for $3 \mathrm{~min}$ and stored at $-70^{\circ} \mathrm{C}$. Samples were thawed and incubated at $37^{\circ} \mathrm{C}$ for $10 \mathrm{~min}$. The tested sample $(200 \mu \mathrm{l})$ was added to each tube. The absorbance of the resulting solution at $450 \mathrm{~nm}$ was measured with an automatic biochemical analyzer (DXC600; Beckman-Coulter). LDH activity was calculated against a sodium pyruvate calibration curve.
Statistical analysis. Results were expressed as mean \pm SD. Comparison between more than two groups was performed by one-way ANOVA and Student Newman-Keuls test. $\mathrm{P}<0.05$ was considered to indicate a statistically significant result.

\section{Results}

LPS treatment increases $C B S$ and $H_{2}$ S synthesis in BRL cells. The expression of CBS was measured in BRL cells treated with $10 \mu \mathrm{g} / \mathrm{ml}$ LPS, the main ingredient in bacterial endotoxin, which was used to injure BRL cells. RT-PCR demonstrated that stimulation with LPS increased CBS mRNA over time from 4 to $24 \mathrm{~h}(\mathrm{P}<0.05$; Fig. 1A). Western blot analysis showed that CBS protein in BRL cells was stimulated by LPS, increasing significantly $(\mathrm{P}<0.05$; Fig. $1 \mathrm{~B})$. The $\mathrm{H}_{2} \mathrm{~S}$ production of BRL cells increased markedly $(\mathrm{P}<0.01$; Table I). We used LDH as a common index for cell damage and observed that LDH in the culture medium significantly increased from 4 to $24 \mathrm{~h}$ after LPS treatment $(\mathrm{P}<0.05$; Table II). In the early stages of apoptosis, mitochondrial cytochrome $c$ can be detected in the cytoplasm. Western blot analyses for cytoplasmic proteins indicated that cytochrome $c$ appeared at $4 \mathrm{~h}$ and markedly increased at $12 \mathrm{~h}$ after LPS treatment $(\mathrm{P}<0.05$; Fig. 2A). Cleaved forms of caspase-3, indicating the activated form, appeared at $12 \mathrm{~h}$ and increased at $24 \mathrm{~h}$ after LPS treatment $(\mathrm{P}<0.05$; Fig. $2 \mathrm{~B})$. FCM 
Table II. Alteration of culture supernatant LDH (U/l).

\begin{tabular}{lcccc}
\hline Groups & Control & $4 \mathrm{~h}$ & $12 \mathrm{~h}$ & $24 \mathrm{~h}$ \\
\hline LPS group & $40.33 \pm 2.08$ & $52.27 \pm 10.90$ & $76.20 \pm 3.27^{\mathrm{a}, \mathrm{b}}$ & $118.17 \pm 23.58^{\mathrm{b}, \mathrm{c}}$ \\
AOAA+LPS group & $40.31 \pm 2.11$ & $51.33 \pm 2.31$ & $113.67 \pm 5.69^{\mathrm{c}, \mathrm{d}}$ & $186.33 \pm 6.43^{\mathrm{c}, \mathrm{d}}$ \\
AOAA group & $40.34 \pm 2.01$ & $46.01 \pm 7.01$ & $65.00 \pm 5.29^{\mathrm{a}, \mathrm{b}}$ & $100.33 \pm 2.52^{\mathrm{c}, \mathrm{d}}$ \\
CBS siRNA+LPS group & $40.28 \pm 1.97$ & $52.21 \pm 5.27$ & $109.16 \pm 3.42^{\mathrm{c}, \mathrm{d}}$ & $182.41 \pm 5.27^{\mathrm{c}, \mathrm{d}}$ \\
CBS siRNA group & $40.31 \pm 2.07$ & $44.21 \pm 3.23$ & $49.12 \pm 3.42$ & $56.22 \pm 5.55$ \\
\hline
\end{tabular}

${ }^{\mathrm{a}} \mathrm{P}<0.05$ vs. control group, ${ }^{\mathrm{b}} \mathrm{P}<0.05$ vs. $4 \mathrm{~h}$ group, ${ }^{\mathrm{C}} \mathrm{P}<0.01$ vs. control group, ${ }^{\mathrm{d}} \mathrm{P}<0.01$ vs. $4 \mathrm{~h}$ group. LPS, lipopolysaccharide; AOAA, aminooxyacetic acid; AOAA+LPS, pretreated with AOAA prior to the addition of LPS in BRL cells; CBS siRNA, transfection of CBS siRNA in BRL cells; CBS siRNA+LPS, pretreated with CBS siRNA prior to the addition of LPS in BRL cells. LDH, lactate dehydrogenase; CBS, cystathionine $\beta$-synthase; siRNA, small interference RNA.

Table III. Variation of apoptosis rate in BRL cells (\%).

\begin{tabular}{|c|c|c|c|c|}
\hline Groups & Control & $4 \mathrm{~h}$ & $12 \mathrm{~h}$ & $24 \mathrm{~h}$ \\
\hline LPS group & $0.7 \pm 0.1$ & $12.8 \pm 0.2^{\mathrm{a}}$ & $50.3 \pm 0.5^{\mathrm{b}}$ & $70.9 \pm 0.3^{b}$ \\
\hline AOAA+LPS group & $0.7 \pm 0.1$ & $24.6 \pm 0.3^{c}$ & $33.2 \pm 0.5^{\mathrm{c}}$ & $31.8 \pm 0.4^{\mathrm{d}}$ \\
\hline AOAA group & $0.7 \pm 0.1$ & $2.8 \pm 0.2$ & $7.4 \pm 0.8$ & $8.5 \pm 0.6$ \\
\hline CBS siRNA+LPS group & $0.7 \pm 0.1$ & $24.9 \pm 0.7^{\mathrm{c}}$ & $34.1 \pm 0.2^{\mathrm{c}}$ & $31.3 \pm 0.2^{\mathrm{d}}$ \\
\hline CBS siRNA group & $0.7 \pm 0.1$ & $2.9 \pm 0.1$ & $7.9 \pm 0.4$ & $9.1 \pm 0.3$ \\
\hline
\end{tabular}

${ }^{a} \mathrm{P}<0.05$ and ${ }^{b} \mathrm{P}<0.01$ vs. control group; ${ }^{\mathrm{P}} \mathrm{P}<0.05$ and ${ }^{\mathrm{d}} \mathrm{P}<0.01$ vs. LPS group. LPS, lipopolysaccharide; AOAA, aminooxyacetic acid; AOAA+LPS, pretreated with AOAA prior to the addition of LPS in BRL cells; CBS siRNA, transfection of CBS siRNA in BRL cells; CBS siRNA+LPS, pretreated with CBS siRNA prior to the addition of LPS in BRL cells. CBS, cystathionine $\beta$-synthase; siRNA, small interference RNA.
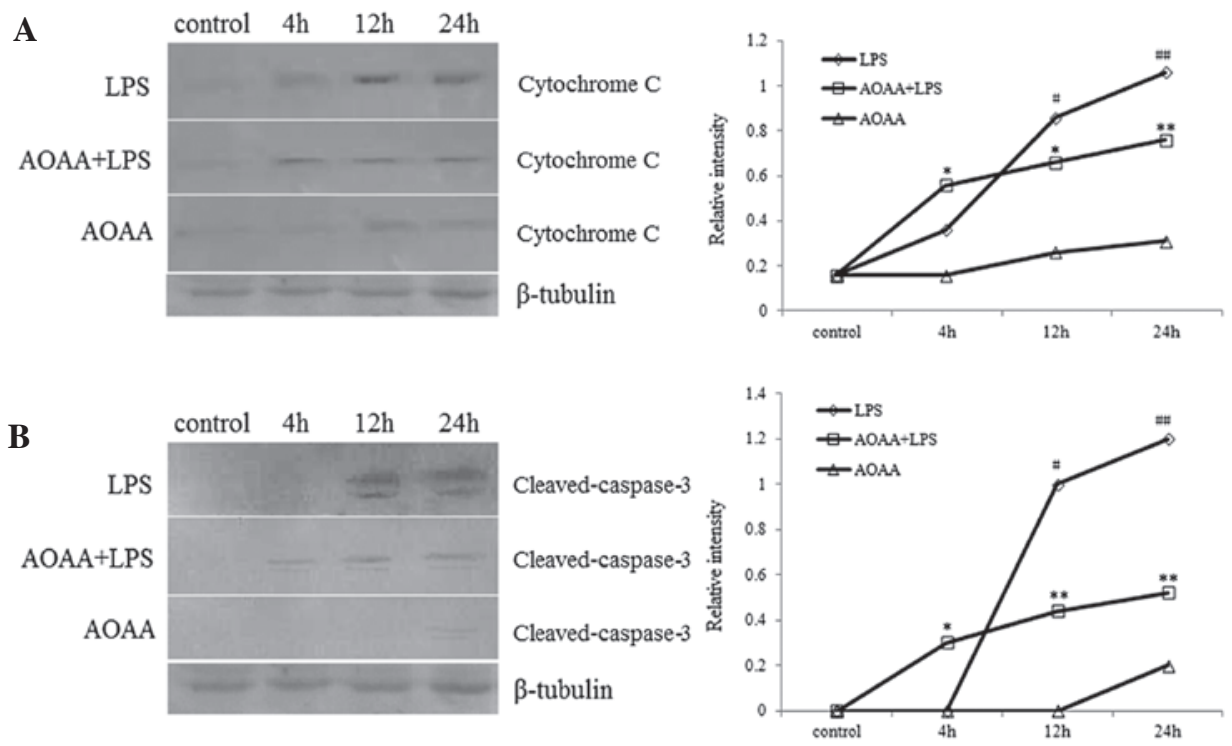

Figure 2. Western blot analysis of cytochrome $c$ and cleaved caspase-3 in BRL cells after LPS-induced apoptosis. Cells were pretreated with or without the CBS inhibitor AOAA ( $3 \mathrm{mM}$ ) for $20 \mathrm{~min}$ before addition of LPS $(10 \mu \mathrm{g} / \mathrm{ml}$ ). At the indicated times, cells were collected for western blot analysis. (A) Variation in cytochrome $c$ expression. (B) Alternation of cleaved caspase- 3 protein. Data are representative of 3 independent experiments. ${ }^{\#} \mathrm{P}<0.05$, ${ }^{\# \#} \mathrm{P}<0.01 \mathrm{vs}$. control; ${ }^{*} \mathrm{P}<0.05,{ }^{* *} \mathrm{P}<0.01$ vs. LPS group. CBS, cystathionine $\beta$-synthase; LPS, lipopolysaccharide; AOAA, aminooxyacetic acid.

detection showed that apoptosis of BRL cells increased gradually from 4 to $24 \mathrm{~h}$ after LPS incubation $(\mathrm{P}<0.05$; Table III and Fig. 3A). By contrast, variation in the mitochondrial membrane potential decreased from 4 to $24 \mathrm{~h}(\mathrm{P}<0.05$; Fig. $4 \mathrm{~A})$.
LPS-induced $\mathrm{CBS}-\mathrm{H}_{2} \mathrm{~S}$ synthesis is inhibited by AOAA or $C B S$ SiRNA. BRL cells were pretreated with the CBS inhibitor AOAA $(3 \mathrm{mM})$ for $20 \mathrm{~min}$ prior to the addition of $10 \mu \mathrm{g} / \mathrm{ml} \mathrm{LPS}$. At 4,12 and $24 \mathrm{~h}$, production of $\mathrm{H}_{2} \mathrm{~S}$ in the AOAA+LPS group 

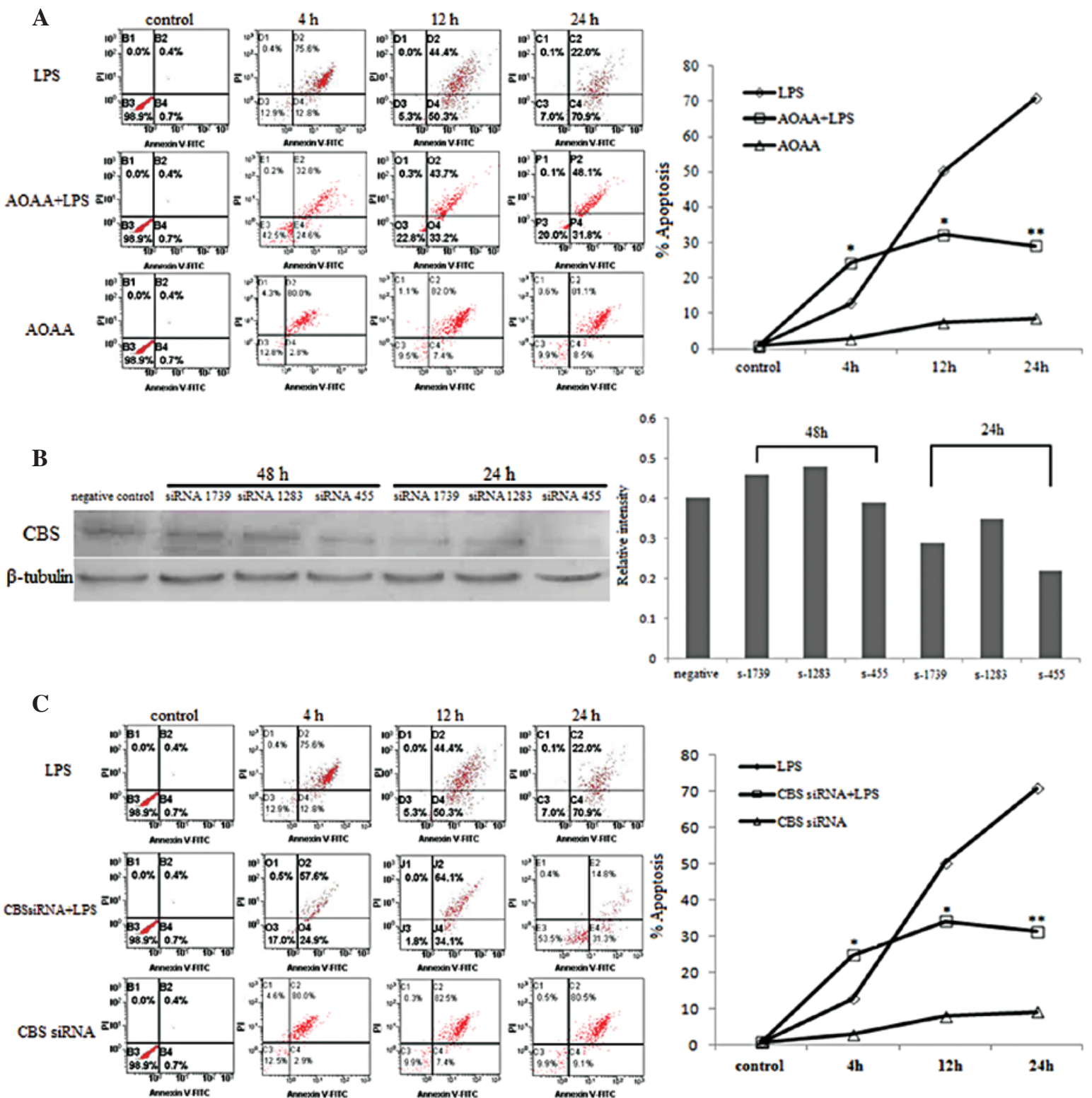

Figure 3. Effects of endogenous CBS on the apoptosis rates in BRL cells. (A) Apoptosis of BRL cells detected by FCM. Cells were pretreated with or without the CBS inhibitor AOAA $(3 \mathrm{mM})$ for $20 \mathrm{~min}$ before the addition of LPS $(10 \mu \mathrm{g} / \mathrm{ml})$. At the indicated time, cells were collected for FCM. (B) Western blot analysis of endogenous CBS in cells treated with CBS siRNA. After transfection ( 24 and $48 \mathrm{~h}$ ) with 3 different siRNAs, BRL cells were subjected to western blot analysis to detect CBS protein to determine the most efficient siRNA sequence and response time. (C) Apoptosis rate of BRL cells by FCM. After transfection with CBS siRNA, cells were treated with $10 \mu \mathrm{g} / \mathrm{ml}$ LPS for the indicated time. Data are representative of 3 independent experiments. ${ }^{*} \mathrm{P}<0.05,{ }^{* *} \mathrm{P}<0.01$ vs. LPS group. CBS, cystathionine $\beta$-synthase; LPS, lipopolysaccharide; FCM, flow cytometry; siRNA, small interference RNA; AOAA, aminooxyacetic acid.

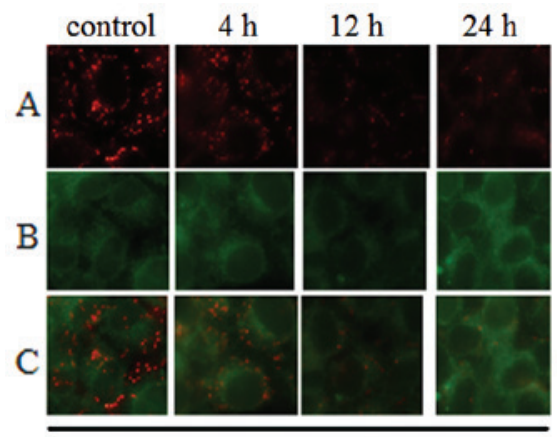

LPS

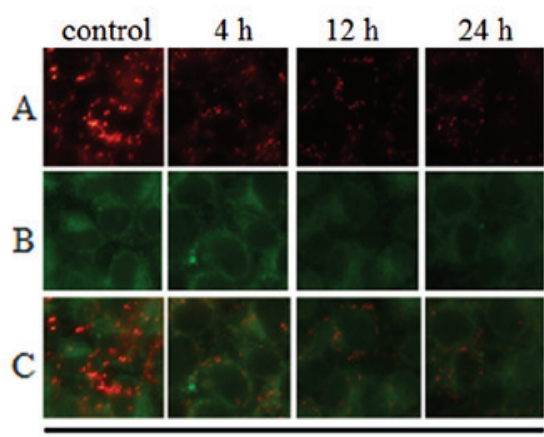

AOAA+LPS

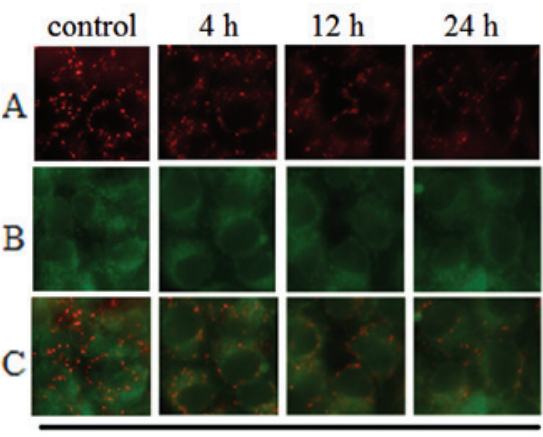

AOAA

Figure 4. Variation in mitochondrial membrane potential in LPS-induced BRL cell apoptosis by fluorescence microscopy. BRL cells were cultured on coverslips prepositioned in 6-well plates overnight. Magnification, $\mathrm{x} 400$. (A) Red fluorescence is the polymer dye. (B) Green fluorescence is the monomer dye. (C) Overlap of A and B. LPS, lipopolysaccharide; AOAA, aminooxyacetic acid. 
decreased significantly compared to the LPS alone group $(\mathrm{P}<0.05$; Table I) and LDH in the culture supernatant of the AOAA+LPS group increased markedly at $12 \mathrm{~h}(\mathrm{P}<0.01$; Table II). Western blot analyses revealed that intracytoplasmic cytochrome $c$ clearly increased in the AOAA+LPS group at $4 \mathrm{~h}$ but decreased at $12 \mathrm{~h}$ after LPS treatment compared to the LPS alone group $(\mathrm{P}<0.05$; Fig. $2 \mathrm{~A})$. Although the level of cleaved caspase-3 fragments in the AOAA+LPS group was higher than in the LPS group at $4 \mathrm{~h}$, LPS-induced detection of the cleaved caspase- 3 fragment was strongly attenuated by AOAA at both 12 and $24 \mathrm{~h}(\mathrm{P}<0.01$; Fig. 2B). Detection by FCM indicated that apoptosis in the AOAA+LPS group increased at $4 \mathrm{~h}$ and decreased at 12 and $24 \mathrm{~h}$ compared to the LPS alone group $(\mathrm{P}<0.05$; Table III and Fig. 3A). The variation in mitochondrial membrane potential in the AOAA+LPS group revealed a trend opposite to apoptosis compared to the LPS group (Fig. 4).

After the transfection with CBS siRNA, the addition of LPS to BRL cell cultures resulted in a significant decrease in $\mathrm{H}_{2} \mathrm{~S}$ production compared to the LPS alone group $(\mathrm{P}<0.05$; Table I). Apoptosis as detected by FCM increased in the CBS siRNA+LPS group relative to the LPS group at $4 \mathrm{~h}$ $(\mathrm{P}<0.05$; Table III and Fig. 3C). However, apoptosis in the CBS siRNA+LPS group decreased significantly at 12 and $24 \mathrm{~h}$ compared to the LPS group ( $\mathrm{P}<0.05$; Table III and Fig. 3C).

The effect of AOAA on BRL cells. When the CBS inhibitor AOAA was added to BRL cells at $3 \mathrm{mM}$, synthesis of $\mathrm{H}_{2} \mathrm{~S}$ decreased over time $(\mathrm{P}<0.05$; Table I). A similar affect was observed with transfection of BRL cells with CBS siRNA; CBS downregulation markedly decreased the level of $\mathrm{H}_{2} \mathrm{~S}$ in BRL cells $(\mathrm{P}<0.05$; Table I). $\mathrm{LDH}$ in the culture supernatant of BRL cells increased in the presence of AOAA $(\mathrm{P}<0.05$; Table II), but western blot analyses showed that AOAA treatment did not alter the levels of intracytoplasmic cytochrome $c$ or cleaved caspase-3 (Fig. 2), suggesting that AOAA had a minimal affect on BRL cell apoptosis. AOAA had little effect on apoptosis or MMP. These results demonstrate that LPS-induced apoptosis of BRL cells could be blocked by the CBS inhibitor AOAA.

\section{Discussion}

$\mathrm{H}_{2} \mathrm{~S}$, named the third gaseous transmitter following nitric oxide and carbon monoxide, may be trans-membrane transported in a receptor-independent manner and activate various cellular targets (17). Particularly in the treatment of inflammation and ischemia-reperfusion injury, the enzyme CSE and $\mathrm{H}_{2} \mathrm{~S}$ are an attractive pharmacological agent $(9,18,19)$. As the primary $\mathrm{H}_{2} \mathrm{~S}$-generating organ in vivo, liver possesses the enzymes CSE and CBS (4). However, the enzyme CSE has been given more attention for its involvement in physiological and pathological conditions (20-24). Whether the $\mathrm{CBS}-\mathrm{H}_{2} \mathrm{~S}$ synthesis plays an important role in the modulation of hepatocyte apoptosis remains unknown.

In the present study, we treated the hepatic cell line BRL with LPS to generate an acute injury model of hepatocytes with the aim of observing the effect of the endogenous $\mathrm{CBS}-\mathrm{H}_{2} \mathrm{~S}$ synthesis on inflammatory lesions of hepatocytes. Our results indicate that CBS exists in the rat hepatic cell line BRL, as previously described (2). LPS treatment results in the upregulation of CBS mRNA and protein in BRL cells, with a corresponding increase in total $\mathrm{H}_{2} \mathrm{~S}$ production. The apoptosis of BRL cells detected by FCM increased over time with a corresponding decrease in MMP. The appearance of cytochrome $c$ in the cytoplasm increased and caspase-3 was activated by LPS treatment. The addition of the CBS inhibitor AOAA or transfection with CBS siRNA prior to LPS treatment in BRL cells resulted in an increase in cell apoptosis but no significant change in total $\mathrm{H}_{2} \mathrm{~S}$ production at $4 \mathrm{~h}$ compared to an LPS alone control. However, the apoptosis of BRL cells decreased at $12 \mathrm{~h}$ and the $\mathrm{H}_{2} \mathrm{~S}$ production also decreased, suggesting that endogenous CBS has short-term anti-apoptosis effects, and promotes apoptosis later. A possible explanation is CSE, another main endogenous enzyme involved in $\mathrm{H}_{2} \mathrm{~S}$ generation $(22,23)$. We hypothesize that since AOAA or CBS siRNA does not inhibit the function of endogenous CSE, $\mathrm{H}_{2} \mathrm{~S}$ synthesis continued, and no significant change in total $\mathrm{H}_{2} \mathrm{~S}$ production was observed between the AOAA+LPS and LPS alone groups. However, over time, endogenous CSE could not continue to enhance $\mathrm{H}_{2} \mathrm{~S}$ synthesis. A similar tendency was observed with cytochrome $c$ and cleaved caspase-3. Initially, cytoplasmic cytochrome $c$ was clearly enhanced in BRL cells pretreated with AOAA prior to the addition of LPS, however, the expression then decreased compared to cells treated with LPS alone. At $4 \mathrm{~h}$, cleaved caspase- 3 appeared, suggesting activation, although the amount of cleaved caspase- 3 was less than that in cells stimulated by LPS alone after $12 \mathrm{~h}$.

In conclusion, our results indicate that endogenous $\mathrm{CBS}-\mathrm{H}_{2} \mathrm{~S}$ synthesis in BRL cells may regulate apoptosis induced by LPS, partly by involving the mitochondrial pathway. The course of regulation is complex and may be anti-apoptotic in the short-term but pro-apoptotic in the long-term. These results may provide references for the research and development of clinical treatments. The specific mechanism of the regulation and interaction of endogenous $\mathrm{H}_{2} \mathrm{~S}$ synthesis requires further investigation.

\section{Acknowledgements}

This study was supported by a project funded by the Priority Academic Program Development of Jiangsu Higher Education Institutions (PAPD).

\section{References}

1. Stipanuk MH and Beck PW: Characterization of the enzymic capacity for cysteine desulphhydration in liver and kidney of the rat. Biochem J 206: 267-277, 1982.

2. Swaroop M, Bradley K, Ohura T, Tahara T, Roper MD, Rosenberg LE and Kraus JP: Rat cystathionine- $\beta$-synthase. Gene organization and alternative splicing. J Biol Chem 267: 11455-11461, 1992.

3. Shibuya N, Tanaka M, Yoshida M, Ogasawara Y, Togawa T, Ishii K and Kimura H: 3-Mercaptopyruvate sulfurtransferase produces hydrogen sulfide and bound sulfane sulfur in the brain. Antioxid Redox Signal 11: 703-714, 2009.

4. Zhao W, Ndisang JF and Wang R: Modulation of endogenous production of $\mathrm{H}_{2} \mathrm{~S}$ in rat tissues. Can J Physiol Pharmacol 81: 848-853, 2003.

5. Wang R: Two's company, three's a crowd: can $\mathrm{H}_{2} \mathrm{~S}$ be the third endogenous gaseous transmitter? FASEB J 16: 1792-1798, 2002.

6. Moore PK, Bhatia M and Moochhala S: Hydrogen sulfide: from the smell of the past to the mediator of the future? Trends Pharmacol Sci 24: 609-611, 2003. 
7. Kimura Y, Dargusch R, Schubert D and Kimura H: Hydrogen sulfide protects HT22 neuronal cells from oxidative stress. Antioxid Redox Signal 8: 661-670, 2006.

8. Yang GD, Yang W, Wu LY and Wang $\mathrm{R}: \mathrm{H}_{2} \mathrm{~S}$, endoplasmic reticulum stress, and apoptosis of insulin-secreting beta cells. J Biol Chem 282: 16567-16576, 2007.

9. Li L, Bhatia M and Moore PK: Hydrogen sulphide - a novel mediator of inflammation? Curr Opin Pharmacol 6: 125-129, 2006.

10. Gardiner SM, Kemp PA, March JE and Bennett T: Regional haemodynamic responses to infusion of lipopolysaccharide in conscious rat: effects of pre- or post-treatment with glibenclamide. Br J Pharmacol 128: 1772-1778, 1999.

11. Shi W, Cui N, Wu Z, Yang Y, Zhang S, Gai HY, Zhu DL and Jiang C: Lipopolysaccharides up-regulate Kir6.1/SUR2B channel expression and enhance vascular KATP channel activity via NF- $\kappa \mathrm{B}$-dependent signaling. J Biol Chem 285: 3021-3029, 2010.

12. Zhao W, Zhang J, Lu Y and Wang R: The vasorelaxant effect of $\mathrm{H}_{2} \mathrm{~S}$ as a novel endogenous gaseous KATP channel opener. EMBO J 20: 6008-6016, 2001.

13. Szabo G, Mandrekar P and Dolganiuc A: Innate immune response and hepatic inflammation. Semin Liver Dis 27: 339-350, 2007.

14. Szabo G, Romics L Jr and Frendl G: Liver in sepsis and systemic inflammatory response syndrome. Clin Liver Dis 6: 1045-1066, 2002.

15. Jha S, Calvert JW, Duranski MR, Ramachandran A and Lefer DJ: Hydrogen sulfide attenuates hepatic ischemia-reperfusion injury: role of antioxidant and antiapoptotic signaling. Am J Physiol Heart Circ Physiol 295: H801-H806, 2008.
16. Yang G, Sun X and Wang R: Hydrogen sulfide-induced apoptosis of human aorta smooth muscle cells via the activation of mitogenactivated protein kinases and caspase-3. FASEB J 18: 1782-1784, 2004.

17. Wang R: The gasotransmitter role of hydrogen sulfide. Antioxid Redox Signal 5: 493-501, 2003.

18. Li L, Bhatia M, Zhu YZ, Zhu YC, Ramnath RD, Wang ZJ, Anuar FB, Whiteman M, Salto-Tellez M and Moore PK: Hydrogen sulfide is a novel mediator of lipopolysaccharideinduced inflammation in the mouse. FASEB J 19: 1196-1198, 2005.

19. Hui Y, Du J, Tang C, Bin G and Jiang H: Changes in arterial hydrogen sulfide $\left(\mathrm{H}_{2} \mathrm{~S}\right)$ content during septic shock and endotoxin shock in rats. J Infect 47: 155-160, 2003.

20. Zhang H,Zhi L, Moore PK and Bhatia M: Role of hydrogen sulfide in cecal ligation and puncture-induced sepsis in the mouse. Am J Physiol Lung Cell Mol Physiol 290: 1193-1201, 2006.

21. Collin M, Anuar FB, Murch O, Bhatia M, Moore PK and Thiemermann C: Inhibition of endogenous hydrogen sulfide formation reduces the organ injury caused by endotoxemia. Br J Pharmacol 146: 498-505, 2005.

22. Li L, Salto-Tellez M, Tan CH, Whiteman M and Moore PK GYY4137, a novel hydrogen sulfide-releasing molecule, protects against endotoxic shock in the rat. Free Radic Biol Med 47: 103-113, 2009

23. Awata S, Nakayama K, Suzuki I and Kodama H: Effect of cysteine on the inactivation of cystathionine gamma lyase by DL-propargylglycine. Acta Med Okayama 43: 329-335, 1989.

24. Dulak NC and Shing YW: Large scale purification and further characterization of a rat liver cell conditioned medium multiplication stimulating activity. J Cell Physiol 90: 127-137, 1977. 